\title{
A GAME TO TEACH AND APPLY DESIGN THINKING FOR INNOVATION
}

\author{
UM JOGO PARA ENSINAR E APLICAR O DESEIGN THINKING PARA INOVAÇÃO
}

UN JUEGO PARA ENSEÑAR Y APLICAR EL DESIGN THINKING EN LA INNOVACIÓN

\author{
Ana Paula Kloeckner ${ }^{1}$ \\ Jonatas Ost Scherer ${ }^{2}$ \\ José Luís Duarte Ribeiro ${ }^{3}$
}

\section{Cite as - American Psychological Association (APA)}

Kloeckner, A. P., Scherer, J. O., \& Ribeiro, J. L. D. (2021, Sept./Dec.). A game to teach and apply design thinking for innovation. International Journal of Innovation - IJI, São Paulo, 9(3), 557-587.

https://doi.org/10.5585/iji.v9i3.20286.

\begin{abstract}
Objective: Develop and apply a game to facilitate the use of design thinking for innovation.

Method: The construction of the game was based upon the Constructivism Theory. The game was developed following the steps of: (i) understanding the target audience and the context; (ii) defining learning objectives; (iii) structuring the experience; (iv) identifying resources and applying gamification elements; (v) evaluation.
\end{abstract}

Originality/Relevance: Design Thinking emerges as an alternative to improve the innovation process in companies. To facilitate this innovation process, this paper presents a game, through its development and application, based on the principles and stages of Design Thinking, focusing on difficulties of its implementation.

Results: The game provides an iterative passage through all stages of the design thinking, giving a holistic view of the process, starting with a deep understanding of the problem, and coming to a design solution.

Social / management contributions: The results of the game application have shown its potential to: (i) ease teamwork, avoiding negative discussions and providing active participation from all students; (ii) lead to insight generation in a comprehensible way, making clear the difference between insights and ideas; (iii) simplify the use of inspiring methods and techniques (such as Persona, Empathy Map and Napkin Pitch); (iv) develop creative confidence; (v) provide a pleasant and motivating learning environment for collaborative multidisciplinary work.

Theoretical/Methodological contributions: The game provides a method for building serious games and the game as a method of applying Design Thinking for Innovation.

Keywords: Innovation. Design. Design thinking. Game.

\section{Resumo}

Objetivo: Desenvolver e aplicar um jogo para facilitar o uso do design thinking para inovação.

\footnotetext{
${ }^{1} \mathrm{PhD}$ in Industrial Engineering, Universidade Federal do Rio Grande do Sul - UFRGS. Porto Alegre - RS, Brasil. anakloeckner@ gmail.com

2 PhD in Industrial Engineering, Universidade Federal do Rio Grande do Sul - UFRGS. Porto Alegre - RS, Brasil. jonatas.scherer@ufrgs.br

$3 \mathrm{PhD}$ in Civil Engineering, Universidade Federal do Rio Grande do Sul - UFRGS. Porto Alegre - RS, Brasil. ribeiro@ producao.ufrgs.br
} 
Método: A construção do jogo foi baseada na Teoria do Construtivismo. O jogo foi desenvolvido seguindo as etapas de: (i) compreensão do público-alvo e do contexto; (ii) definir objetivos de aprendizagem; (iii) estruturação da experiência; (iv) identificar recursos e aplicar elementos de gamificação; (v) avaliação.

Originalidade / Relevância: O Design Thinking surge como alternativa para melhorar o processo de inovação nas empresas. Para facilitar esse processo de inovação, este artigo apresenta um jogo, por meio de seu desenvolvimento e aplicação, baseado nos princípios e etapas do Design Thinking, com foco nas dificuldades de sua implementação.

Resultados: O jogo fornece uma passagem iterativa por todas as fases do design thinking, dando uma visão holística do processo, começando com uma compreensão profunda do problema e chegando a uma solução de design.

Contribuições sociais / gerenciais: Os resultados da aplicação do jogo mostraram seu potencial para: (i) facilitar o trabalho em equipe, evitando discussões negativas e proporcionando a participação ativa de todos os alunos; (ii) levar à geração de insights de forma compreensível, deixando clara a diferença entre insights e ideias; (iii) simplificar o uso de métodos e técnicas inspiradoras (como Persona, Empathy Map e Guardanapo); (iv) desenvolver confiança criativa; (v) proporcionar um ambiente de aprendizagem agradável e motivador para o trabalho multidisciplinar colaborativo.

Contribuições teórico-metodológicas: $O$ jogo fornece um método para a construção de serious games e o jogo como método de aplicação do Design Thinking para a inovação.

Palavras-chave: Inovação. Design. Design thinking. Game.

\section{Resumen}

Objetivo: Desarrollar y aplicar un juego para facilitar el uso del Design Thinking para la innovación. Método: La construcción del juego se basó en la Teoría del Constructivismo. El juego se desarrolló siguiendo los pasos de: (i) comprender al público objetivo y el contexto; (ii) definición de objetivos de aprendizaje; (iii) estructurar la experiencia; (iv) identificación de recursos y aplicación de elementos de gamificación; (v) evaluación.

Originalidad / Relevancia: El Design Thinking surge como una alternativa para mejorar el proceso de innovación en las empresas. Para facilitar este proceso de innovación, este trabajo presenta un juego, a través de su desarrollo y aplicación, basado en los principios y etapas del Design Thinking, enfocándose en las dificultades de su implementación.

Resultados: el juego proporciona un pasaje iterativo a través de todas las etapas del Design Thinking, brindando una visión holística del proceso, comenzando con una comprensión profunda del problema y llegando a una solución de Design.

Contribuciones sociales / de gestión: Los resultados de la aplicación del juego han demostrado su potencial para: (i) facilitar el trabajo en equipo, evitar discusiones negativas y proporcionar una participación activa de todos los estudiantes; (ii) conducir a la generación de conocimientos de una manera comprensible, dejando clara la diferencia entre conocimientos e ideas; (iii) simplificar el uso de métodos y técnicas inspiradoras (como Persona, Empathy Map y Napkin Pitch); (iv) desarrollar la confianza creativa; (v) proporcionar un entorno de aprendizaje agradable y motivador para el trabajo multidisciplinario colaborativo.

Contribuciones teóricas / metodológicas: El juego proporciona un método para construir juegos serios y el juego como método de aplicación del Design Thinking para la innovación.

Palabras clave: Innovación. Design. Design thinking. Juego.

\section{Introduction}

Even before the presentation of design thinking as an approach for innovation (Brown 2008), some authors (Buchanan 1992; Ho 2001; Liu 1996) already used the term as a way of thinking that was part of the Design discipline. Lloyd (2017) highlights design thinking as more 
than a method since it has emerged and spread beyond the traditional disciplines of Design and can be used to stimulate creativity and to solve problems - which are important cognitive skills for the 21st century (Akcaoglu 2014; Hwang, Wu \& Chen 2012).

Design thinking is a human-centered process, with emphasis on the deep understanding of consumers, targeted at the innovation of products, services, processes, and businesses in a holistic, integrative, creative, and inspiring way. Design thinking translates observations into insights and insights into innovation through an exploratory, iterative, and non-linear process, which leads to unexpected discoveries since the process is fundamentally exploratory. Design thinking is supported by themes that form its mentality: empathy, curiosity, collaboration, experimentation, visualization, flexibility, and continuous learning (Akili 2015; Andreassen et al. 2016; Buchanan 1992; Brown 2008; Brown \& Katz 2009; Brown \& Martin 2015; Carlgren et al. 2016; Gleason \& Cherrez 2020; Davis 2010; Dorst 2011; Ferreira et al. 2015;Goodspreed et al. 2016; Holloway 2009; Hussaini \& Vinnakota 2015; IDEO 2015; Jiao \& Zhang 2015; Johansson \& Woodilla 2009; Koliji 2016; Leverenz 2014; Liedtka 2014; Liedtka e Ogilvie 2011; Lockwood 2009; Luchs et al. 2016; Olsen 2015; Rylander 2009; Uehira e Kay 2009; Sato et al. 2010; Stickdorn \& Schneider 2011; Sköldberg et al. 2013; Seidel e Fixson 2013; To \& Liu 2021; Vianna et al. 2012; Ward et al. 2009).

Based on the importance of design thinking, it should be integrated with models of learning and knowledge production (Burdick and Willis 2011). However, even though Brown and Katz (2009) state that design thinking is a simple and accessible approach, there are some obstacles for its teaching in practice. In addition to these obstacles, there is a gap between academic contents and the needs, interests, and motivations of students in the learning process, as discussed by Barab, Thomas, Dodge, Carteaux \& Tuzun (2005). Cross (1982) already stressed that education should be deliberately designed to increase and develop students' cognitive process and abilities. Schon (1987), in the same context, emphasizes that learning by doing helps developing abilities related to continuous learning and problem solving. Oxman (2004) states that encouraging experimentation through methods of experimental teaching can make knowledge become more accessible and possible.

In a historical context involving design, games, and learning, Talbot (1973) proposed the GRIPS (Gaming Random Interfacing and Problem Structuring) approach for the solution of teaching problems. From the point of view of education and learning, Habraken and Gross (1988) developed a series of games and identified that games provide an adequate environment to work in groups, allowing the isolation of concepts and helping to transform complex questions in simple results. The same authors state that games are a useful way to learn both 
theory and methods of design. Recently, Shih Hu \& Chen (2006) developed an approach to analyze cooperative learning based on games and have concluded that group activities, using games, provide support for cooperation among the participants, which contributes to better results. Some games have already been developed exclusively for education in Design. Shih et al. (2006) developed the Prisoner's Dilemma game aiming to analyze complex cooperation and competition behaviors in design studios. McCain (2014), who presented the game theory, affirms that experimental methods focused on personal interactions are a powerful source of insight generation. Eppler (2016), recently, proposed the Dynagrams, which are visual tools that offer more than just summarized information since they help to bring attention to the discussion. Patrício et al. (2020) used gamification to implement Design Thinking in companies and found that gamification helps to improve practices, collaboration and engagement in these processes.

Based on the mentioned issues, the present study proposes a game to teach design thinking based on the education games development process, that seeks to reach theoretical and practical learning objectives. This game is consistent with the design thinking principles and contributes to overcoming the difficulties for its application. Thus, this paper is organized as follows: section 2 presents a study on the design thinking stages and principles; section 3 discusses the difficulties for teaching design thinking; section 4 presents the methodological procedures used to develop the game; section 5 describes the game for teaching design thinking; section 6 shows the results and discussion of the application of the proposed learning game; and section 7 summarizes conclusions.

\section{Design thinking stages and principles}

Based on the approaches identified in the design thinking literature review, it was possible to observe that, although authors present some stages differently, they describe the same activities or purposes. Thus, the design thinking stages were translated into three macro stages (inspiration, ideation, and prototyping and testing), and five stages: (i) exploration, (ii) insight definition, (iii) idea generation, (iv) idea refinement and (v) prototyping and testing (Table 1).

To support these stages, design thinking can be translated into eight principles: (i) iterate, (ii) immerse yourself, (iii) empathize, (iv) be intuitive; (v) be visual, (vi) inspire, (vii) be generative, (viii) prototype and (ix) be creative confident. 


\section{Table 1}

Design thinking stages and description

\begin{tabular}{l|l|l}
\hline \multicolumn{1}{c|}{ Stages } & \multicolumn{1}{c}{ Description } & \multicolumn{1}{c}{ Authors } \\
\hline 1. Exploration & $\begin{array}{l}\text { This stage deeply explores the factors } \\
\text { associated to people and contexts. }\end{array}$ & $\begin{array}{l}\text { Brown \& Katz 2009; Davis 2010; } \\
\text { IDEO 2015; Liedtka \& Ogilvie 2011; } \\
\text { Seidel \& Fixson 2013; Sitckdorn \& } \\
\text { Schneider 2011 }\end{array}$ \\
\hline 2. Insight Definition & $\begin{array}{l}\text { This stage defines and identifies the } \\
\text { problem, pointing to opportunities that will } \\
\text { lead the search for a design solution. }\end{array}$ & $\begin{array}{l}\text { Brown \& Katz 2009; Carlgren et al. } \\
\text { 2016; Ferreira et al. 2015; IDEO } \\
\text { 2015; Luchs 2016 }\end{array}$ \\
\hline 3. Idea Generation & $\begin{array}{l}\text { This stage involves the generation, } \\
\text { development, and testing of ideas in the } \\
\text { search for design possibilities and } \\
\text { solutions. }\end{array}$ & $\begin{array}{l}\text { Brown \& Katz 2009; Johansson \& } \\
\text { Woodilla 2009; IDEO 2015; Kelley } \\
\text { \& Kelley 2015; Liedtka \& Ogilvie } \\
\text { 2011; Olsen 2009; Sköldberg et al. } \\
\text { 2013; Stickdorn \& Schneider 2011 }\end{array}$ \\
\hline 4. Idea Refinement & $\begin{array}{l}\text { It involves the selection and reduction of } \\
\text { ideas to a lower, manageable number. }\end{array}$ & $\begin{array}{l}\text { Brown 2009; Liedtka \& Ogilvie } \\
\text { 2012; Luchs 2016; Olsen 2015 }\end{array}$ \\
\hline $\begin{array}{l}\text { 5. Prototyping and } \\
\text { Testing }\end{array}$ & $\begin{array}{l}\text { This stage moves from ideas (abstract) to } \\
\text { concrete design solutions }\end{array}$ & $\begin{array}{l}\text { Brown 2009; Jiao \& Zhang 2015; } \\
\text { Liedtka \& Ogilvie 2012; Seidel \& } \\
\text { Fixson 2013 }\end{array}$ \\
\hline
\end{tabular}

Source: Created by the authors.

Iterate comprises working in cycles in a non-linear, emergent, divergent, collaborative, and flexible process that facilitates and reduces the innovation development time. (Akili 2015; Brown \& Katz 2009; Brown \& Martin 2015; Carlgreen et al. 2016; Ferreira, Song, Gomes, Garcia \& Ferreira 2015; Goodspeed et al. 2016; Holloway 2009; Hussaini \& Vinnakota 2016; Leverenz 2014; Liedtka 2014; Liedtka \& Ogilvie 2012; Luchs 2016; Olsen 2015; Rylander 2009; Sato 2009; Sato, Lucente, Meyer \& Mzarek 2010).

Immerse yourself comprises promoting a deep immersion, understanding the context of the problem, knowing the current reality regarding the environment, social factors, market trends, and the ways that people deal with the problem, coping with the real world natural complexity, questioning as many things as possible concerning the researched theme, looking beyond the immediate boundaries of the problem, searching for the roots of the problem, being curious and expecting to find the unexpected (Akili 2015; Brown \& Katz 2009; Davis 2010; Ferreira et al. 2015; Holloway 2009; Liedtka \& Ogilvie 2011; Luchs 2016; Olsen 2015; Rylander 2009; Sköldberg et al. 2013; Vianna, Vianna, Adler, Lucena \& Russo 2012).

Empathize involves the comprehension of the user's perspective (empathy), putting oneself in the user's position to deeply understand their needs, wishes, thoughts, feelings, experiences, interactions, and behaviors, including extreme users (Andreassen et al. 2016; 
Brown \& Katz 2009; Brown \& Martin 2015; Carlgren et al. 2016; Goodspeed et al. 2016; Holloway 2009; IDEO 2015; Liedtka \& Ogilvie 2012; Luchs et al 2016; Olsen 2015; Rylander 2009; Uehira \& Kay 2009; Ward, Runcie \& Morris 2009).

Be Intuitive is the creative integration of the information gathered, synthesizing data, and making new connections between the elements involved. Intuition is a condensation of pieces of information through a process of rapid thinking that relates past experiences to important information of the present moment, not necessarily going through cognition processes (Cervo \& Brevian 2002; Davis 2010; Sato et al. 2010). Intuition is connected to the creative capacity and, when stimulated, facilitates insight generation (Brown \& Martin 2015; Cervo \& Brevian 2002; Olsen 2015;).

Be Visual comprises making ideas visual, developing a common view of the proposed solutions, helping knowledge and concept externalization. The use of visual representations is important since it makes the expression of complex thoughts easier, demonstrating relations and creating a common view between the team members (Buchanan 1992; Carlgren et al. 2016; Ferreira et al. 2015; Holloway 2009; Liedtka \& Ogilvie 2011; Luchs 2016; Olsen 2015; Rylander 2009; Sato et al. 2010; Ward et al. 2009).

Inspire involves team motivation and must be done through insight generation, which will point to new perspectives that converge to the problem solution (Brown \& Katz 2009; Buchanan 1992; Goodspeed et al. 2016; Liedtka 2014; IDEO 2015; Luchs 2016; Sköldberg et al. 2013; Stickdorn \& Schneider 2011; Ward et al. 2009).

Be Generative contemplates the structured and systematic way of thinking, based on the creative confidence (Kelley \& Kelley 2015), balancing intuition and the analysis of the data obtained in the exploratory process, associating words, exploring new concepts, and integrating new ideas to the existing ones. The higher the number of ideas, the better (Akili 2015; Andreassen et al. 2016; Brown \& Katz 2009; Carlgren et al. 2016; Davis 2010; Dorst 2011; Holloway 2009; Hussaini \& Vinnakota 2015; Koliji 2016; Liedtka \& Ogilvie 2011, 2012; Luchs 2016; Rylander 2009; Sato et al. 2010; Olsen 2015; Ward et al. 2009).

Prototyping involves testing ideas, using the experiment results and constant user feedback to improve the solution. This should be supported by simple prototypes with low detail level, but sufficient to test the concepts. (Brown \& Katz 2009; Brown \& Martin 2015; Carlgren et al. 2016; Davis 2010; Goodspeed et al. 2016; IDEO 2015; Jiao \& Zhang 2015; Liedtka 2014; Liedtka \& Ogilvie 2011; Luchs 2016; Olsen 2015; Stickdorn \& Schneider 2011).

Be Creative Confident regards the creative integration of information through the ability of creating new connections, leading to new paths and possibilities. Kelley and Kelley (2015) 
use the term creative confidence as a way to express the importance of creativity to accomplish successful innovation. Those who have creative confidence have characteristics, such as believing in the creative potential, in the capability of finding solutions to apparently impossible problems, exploring new possibilities, and easily changing directions (Seidel \& Fixson 2013; Vianna et al. 2012).

\section{Difficulties in teaching design thinking}

As presented in the introduction, even though design thinking seems to be a simple and accessible approach, in practice there are some major obstacles for its teaching. Among these obstacles (or difficulties) some can be highlighted: (i) reaching a holistic view of the design thinking process (Noweski et al., 2012; Earle \& Hiz, 2020); (ii) understanding the difference between insights and ideas (Brown; Katz, 2009; IDEO, 2015; Sato et al., 2010; Liedtka, 2014; Vianna et al., 2012); (iii) using methods and techniques at the right moment (Sköldberg et al., 2013; Liedtka, 2015; Carlgren et al. 2016); (iv) the gain of creative confidence associated with real gains in creativity (Rao et al., 2021). Besides that, there are two other elements that must be considered for the effective learning process: (i) motivation (Collins, 1992; Hwang et al., 2012;) and (ii) experimentation (Barab et al., 2005).

Regarding the lack of holistic view, Noweski et al. (2012) states that when a system is presented as a whole, it is necessary to understand each one of the parts that compose it. The traditional teaching way is still targeted at explaining the parts without fully approaching the system, which makes it difficult for students to connect themes and topics.

Concerning the problem of understanding the difference between insights and ideas, the insights, differently from the ideas, are the findings that come from problem immersion and from the identification of an opportunity and must be revealing and inspirational, motivating people for a subsequent moment, which is the idea generation process. Insights are obtained through connections made from the information obtained in the exploratory process of design thinking and, later, will be the foundation for idea building. Ideas (which can emerge from one or more insights), however, are alternatives for the solution, feasible or not, that will later culminate in results through a convergence process (Brown \& Katz 2009; IDEO 2015; Liedtka 2014; Sato et al. 2010). In the idea generation process, Jobst, Köppen, Lindberg, Moritz, Rhinow \& Meinel (2012) highlight the importance of developing the students' creative confidence by using design thinking, but they question which methods and techniques would establish this creative confidence. This leads to the last difficulty aforementioned, regarding the 
use of methods and techniques at the right moment. Carlgren et al. (2016) and Liedtka (2015) point that design thinking is a difficult and controversial concept to be studied due to its multifaceted nature and the lack of coherence between what DT is in academic terms and in practical terms. Furthermore, design thinking is frequently seen only as a method or a group of tools and methods by practitioners and researchers (Liedtka 2015; Sköldberg et al. 2013).

Thus, motivation is an essential element, because it includes understanding the needs and interests of the students, challenging them to answer questions and solve problems, engaging them in real world activities (Barab et al. 2005; Burdick \& Willis 2011). Barab et al. (2005) argues that the education community developed a lot of studies focused on contents to support the learning process, however these studies do not necessarily capture students' interests and motivations. The interest, motivation and engagement in real world activities is more easily achieved by experimentation. Experimentation enables learning by doing, through the practice, action, and reflection about what has been done, understanding the impact on the results generated (Barab et al. 2005; Hwang et al. 2012; Schon 1987).

\section{Method}

Hwang et al. (2012) highlight the need to incorporate learning theory in the development of games for learning. The construction of the game was based upon the Constructivism Theory. The adequacy of the use of Constructivism for the development of games aimed at learning is verified in the literature (Barzilai \& Blau 2014; Kordaki \& Gousiou 2017; Li \& Tsai 2013; Qian \& Clark 2016). According to Constructivism, education must be experimental and experiential (Huang 2011). The learners will actively construct knowledge through their experiences (Huang, Huang \& Tschopp 2010). Thus, the emphasis of the game must be in the learning environment and not in a sequence of instructions (Johansen 1994).

According to the Constructivist Theory, the use of groups during the learning job will enable learners to share knowledge, contributing to learning (Assaraf 2011). Within this perspective, the role of the teacher is not only to transmit information, but to act as a facilitator of the learning process (Bell, Maeng \& Binns 2013; Palmer 2005).

\subsection{Game development process}

The game was developed based on the games for education development process proposed by Huang \& Soman (2013). The five steps proposed by Huang \& Soman (2013) were grouped into four, and a new evaluation step was introduced. The two final steps of the model 
proposed by Huang \& Soman (2013) were grouped in the step of identifying resources and applying gamification elements. The evaluation of the games developed is one of the limitations found in the literature of game development (Dichev \& Dicheva 2017; Faiella \& Ricciardi 2015; Hanus \& Fox 2015; Hernández, Baroni, Bieger, Chmait, Dowe, Hofmann \& Thórisson 2017; Petri \& Wangenheim 2017). In view of that, an evaluation step was inserted with the aim to assess the results of the game development project. Therefore, the game was developed following the steps of: (i) understanding the target audience and the context; (ii) defining learning objectives; (iii) structuring the experience; (iv) identifying resources and applying gamification elements; (v) evaluation.

In the first step of the process, the profile of the students (learners) that would participate in the game was defined, as well as the formation of the groups and their sizes. Besides that, the environment and the time duration of the game were defined.

The learning objectives were defined following Bloom's Revised Taxonomy (Krathwohl 2002). This taxonomy defines the learning objectives in terms of the dimensions of cognitive processes and knowledge. The cognitive dimension process is subdivided into six categories (Anderson \& Krathwohl 2001): (i) remember, (ii) understand, (iii) apply, (iv) analyze, (v) evaluate and (vi) create. While the knowledge dimension encompasses the dimensions of factual knowledge, conceptual knowledge, procedural knowledge, and metacognitive knowledge (Anderson \& Krathwohl 2001).

\section{Table 2}

Profile of the workshop participants for the experience structuration

\begin{tabular}{|c|c|c|c|c|c|}
\hline Participants & Background & Field of work & Profession & Experience & Institution \\
\hline 1 & $\begin{array}{l}\text { Industrial } \\
\text { Engineering }\end{array}$ & $\begin{array}{l}\text { Education and } \\
\text { Research }\end{array}$ & $\begin{array}{l}\text { Professor of Service } \\
\text { Engineering }\end{array}$ & $>10$ years & UFRGS \\
\hline 2 & $\begin{array}{l}\text { Business } \\
\text { Administration }\end{array}$ & $\begin{array}{l}\text { Education and } \\
\text { Research }\end{array}$ & $\begin{array}{l}\text { Professor of } \\
\text { Marketing }\end{array}$ & $>10$ years & UFRGS \\
\hline 3 & Civil Engineering & $\begin{array}{l}\text { Education and } \\
\text { Research }\end{array}$ & $\begin{array}{l}\text { Director of the } \\
\text { Technological } \\
\text { Development Office }\end{array}$ & $>20$ years & UFRGS \\
\hline 4 & $\begin{array}{l}\text { Business } \\
\text { Administration }\end{array}$ & $\begin{array}{l}\text { Education and } \\
\text { Research }\end{array}$ & $\begin{array}{l}\text { Professor of } \\
\text { Strategic } \\
\text { Management } \\
\end{array}$ & $>5$ years & UFCSPA \\
\hline 5 & Civil Engineering & $\begin{array}{l}\text { Education and } \\
\text { Research }\end{array}$ & $\begin{array}{l}\text { Director of } \\
\text { Technological } \\
\text { Incubator }\end{array}$ & $>10$ years & UFRGS \\
\hline 6 & Statistics & $\begin{array}{l}\text { Education } \\
\text { and Research }\end{array}$ & $\begin{array}{l}\text { Professor of } \\
\text { Innovation and } \\
\text { Product } \\
\text { Development }\end{array}$ & $>10$ years & UFRGS \\
\hline
\end{tabular}

Source: Created by the authors based on research data. 
The structuration of the experience was executed in two steps: (i) theoretical and practical foundation, and (ii) game assessment. Initially, a theoretical basis of design thinking, its stages and principles, as well as, the difficulties in teaching design thinking found in the literature were used to format an initial structure. Furthermore, authors experiences teaching design thinking were used to build the game. Then, game structure was assessed by means of a workshop with specialists in teaching and in design thinking (Table 2), and the improvements were incorporated in the game. Experience structuration was assessed qualitatively by specialists using the criteria motivation and user experience proposed by Petri \& Wangenheim (2016).

During the step of identifying resources and applying gamification elements, design thinking resources and tools were used in the game, and gamification elements were also applied. Gamification elements were based on the game attributes identified by Bedwell, Pavlas, Heyne, Lazzara \& Salas et al. (2012): (i) action language, (ii) assessment, (iii) conflict/challenge, (iv) control, (v) environment, (vi) game fiction, (vii) human interaction, (viii) immersion and (ix) rules and goals. The methods and techniques of design thinking were initially selected by the authors based on their experience in teaching design thinking. Afterwards, a workshop with specialists was used to validate the set of methods and techniques selected and the gamification experience proposed (Table 3).

The evaluation of the game was performed through 3 pilot applications. Learning objectives were evaluated through a structured questionnaire. The questionnaire was built following the guidelines of Zikmund, Babin, Carr \& Griffin (2012), Blumberg, Cooper \& Schindler (2014) and Cowles and Nelson (2015). The questionnaire was composed using simple language, short and direct questions that encompassed one single aspect per question, not requiring the respondent to have thought about the issue previously and avoiding questions that require memories of past events (Cowles \& Nelson 2015; Zikmund et al. 2012). To minimize the anchoring effect, the items were randomly presented throughout the questionnaire (Zikmund et al. 2012). Leading and loaded questions were avoided (Cowles \& Nelson 2015; Zikmund et al. 2012). The questions addressed one aspect at a time and the final points of the scale were periodically inverted between positive and negative categories to avoid the halo effect (Blumberg 2014). Questions were randomly presented to minimize the anchoring effect (Zikmund et al. 2012). 


\section{Table 3}

Profile of the specialists participating in the game validation

\begin{tabular}{|c|c|c|c|c|c|}
\hline Participants & Background & $\begin{array}{c}\text { Field of } \\
\text { work }\end{array}$ & Profession & Experience & Institution \\
\hline 1 & $\begin{array}{l}\text { Business } \\
\text { Administration }\end{array}$ & $\begin{array}{l}\text { Education } \\
\text { and Research }\end{array}$ & $\begin{array}{l}\text { Professor of } \\
\text { Entrepreneurship } \\
\text { and Innovation }\end{array}$ & $>20$ years & $\begin{array}{l}\text { University de } \\
\text { Pittsburg, USA }\end{array}$ \\
\hline 2 & $\begin{array}{l}\text { Industrial } \\
\text { Engineering }\end{array}$ & $\begin{array}{l}\text { Education } \\
\text { and Research }\end{array}$ & $\begin{array}{l}\text { Professor and } \\
\text { Researcher in } \\
\text { Artificial } \\
\text { Intelligence and } \\
\text { Technology } \\
\text { Management }\end{array}$ & $>20$ years & $\begin{array}{l}\text { Central } \\
\text { University of } \\
\text { Florida, USA }\end{array}$ \\
\hline 3 & $\begin{array}{l}\text { Industrial } \\
\text { Engineering }\end{array}$ & $\begin{array}{l}\text { Education } \\
\text { and Research }\end{array}$ & $\begin{array}{l}\text { Professor and } \\
\text { Researcher of } \\
\text { Engineering and } \\
\text { Technology }\end{array}$ & $>20$ years & $\begin{array}{l}\text { Universidad de } \\
\text { Carabobo, } \\
\text { Venezuela }\end{array}$ \\
\hline 4 & Civil Engineering & $\begin{array}{l}\text { Education } \\
\text { and Research }\end{array}$ & $\begin{array}{l}\text { Professor and } \\
\text { Researcher of } \\
\text { Entrepreneurship } \\
\text { and Innovation }\end{array}$ & $>10$ years & UFRGS, Brazil \\
\hline 5 & $\begin{array}{l}\text { Business } \\
\text { Administration }\end{array}$ & $\begin{array}{l}\text { Education } \\
\text { and Research }\end{array}$ & $\begin{array}{l}\text { Professor of } \\
\text { Strategic } \\
\text { Management }\end{array}$ & $>5$ years & $\begin{array}{l}\text { UFCSPA, } \\
\text { Brazil }\end{array}$ \\
\hline 6 & Civil Engineering & $\begin{array}{l}\text { Education } \\
\text { and Research }\end{array}$ & $\begin{array}{l}\text { Director of the } \\
\text { Technological } \\
\text { Development } \\
\text { Office }\end{array}$ & $>20$ years & UFRGS, Brazil \\
\hline 7 & $\begin{array}{l}\text { Industrial } \\
\text { Engineering }\end{array}$ & $\begin{array}{l}\text { Education } \\
\text { and Research }\end{array}$ & $\begin{array}{l}\text { Dean of the } \\
\text { Universidad } \\
\text { Nacional Mayor de } \\
\text { San Marcos }\end{array}$ & $>20$ years & $\begin{array}{l}\text { Universidad } \\
\text { Nacional Mayor } \\
\text { de San Marcos, } \\
\text { Perú }\end{array}$ \\
\hline
\end{tabular}

Source: Created by the authors based on research data

The questionnaire used for game evaluation uses a five-point Likert scale. This scale was chosen by its adequate properties for the objective of the proposed assessment (Blumberg 2014; Zikmund et al. 2012). According to Cowles and Nelson (2015), this type of scale is adequate and commonly used to evaluate opinions and attitudes. The number of points in the scale was defined as five by its adequacy in terms of reliability and validity (Maydeu-Olivares et al. 2009) for questions addressing an object/construct (Cox III 1980). Furthermore, Preston and Colman (2000) highlight that five-point scales are easily understood by the respondents.

\section{Results and discussion}

The game has been applied to more than 312 people, with 58 different groups (teams of 5 to 8 people). These groups were composed of undergraduate students, graduate students, 
professors, researchers, and professionals. Nevertheless, in this study, the results obtained with 67 participants, from three different groups will be presented: (i) 18 undergraduate students, (ii) 22 professors and (iii) 26 professionals. Questionnaires were applied to this group based on the learning objectives that will be presented. Thus, quantitative data obtained from the questionnaire application, as well as qualitative results observed will be presented.

\subsection{Understanding the target audience and context}

In the first step, understanding the target audience and context, three main potential user profiles were identified for the game: (i) undergraduate students, for design thinking teaching and the development of competencies; (ii) professors, for the development of competencies to improve teaching; and (iii) market professionals, for design thinking teaching and the development of competencies for innovation and problem solution in companies and in the market. Furthermore, group size was also identified as an important element, therefore, groups were limited to 30 people so adequate support could be given to each group during the activity. Regarding the environment, the need to create a suitable material was identified. The material should enable a proper environment, keeping the students focus on the activity and allowing the conduction to the desired results.

\subsection{Defining learning objectives}

In the second stage, defining learning objectives, the objectives to be reached by means of the game application were identified. Thus, based on the Bloom taxonomy, the objectives were developed, dividing them in the two proposed dimensions: (i) cognitive process and, (ii) knowledge.

Within the cognitive process dimension in its six categories, nine objectives were defined: (i) identifying the challenge elements (remember), (ii) categorizing the elements (understand), (iii) translating the elements (understand), (iv) summarizing the information, translating into a new challenge (understand), (v) generating ideas for the solution of the challenge (create), (vi) selecting ideas for the final solution (analyze), (vii) planning how to execute ideas (create), (viii) executing ideas (apply) and (ix) testing the ideas (analyze).

In the knowledge dimensions, from the four categories, three were developed: (i) identifying the challenge elements (factual), (ii) understanding the difference between insights and ideas (conceptual) and (iii) using methods and techniques at the right moment (procedural). 
Each one of the objectives presented was linked to the principles and to the methods and techniques. For each one of the objectives, the results observed were presented, as shown in Table 4 and Table 5.

\section{Table 4}

Learning objectives and results observed - knowledge dimension

\begin{tabular}{|c|c|c|c|}
\hline Objectives & Categories & $\begin{array}{c}\text { Methods and } \\
\text { Techniques }\end{array}$ & Observed Outcomes \\
\hline $\begin{array}{l}\text { Identifying } \\
\text { challenge elements }\end{array}$ & Factual & Inspiration Map & $\begin{array}{l}\text { Topics of the inspiration map } \\
\text { developed a broad and deep view of } \\
\text { the problem. }\end{array}$ \\
\hline $\begin{array}{l}\text { Understanding the } \\
\text { difference between } \\
\text { Insights and Ideas }\end{array}$ & Conceptual & $\begin{array}{l}\text { Inspiration Map x Ideas } \\
\text { Board }\end{array}$ & $\begin{array}{l}\text { The groups generated a big quantity } \\
\text { of insights through the Inspiration } \\
\text { Map and then transformed insights in } \\
\text { ideas using the Ideas Board. }\end{array}$ \\
\hline $\begin{array}{l}\text { Using methods and } \\
\text { techniques at the } \\
\text { right moment }\end{array}$ & Procedural & $\begin{array}{l}\text { Inspiration Map x Ideas } \\
\text { Board }\end{array}$ & $\begin{array}{l}\text { The students understood the } \\
\text { importance of the sequence of } \\
\text { methods and techniques used to } \\
\text { support the results. }\end{array}$ \\
\hline
\end{tabular}

Source: Created by the authors 


\section{Table 5}

Learning objectives and Results observed - cognitive process dimension

\begin{tabular}{|c|c|c|c|c|}
\hline Objectives & Categories & Principles related & $\begin{array}{c}\text { Methods and } \\
\text { Techniques }\end{array}$ & Observed Outcomes \\
\hline Identifying the challenge elements & Remember & $\begin{array}{l}\text { Immerse yourself } \\
\text { Empathize }\end{array}$ & $\begin{array}{l}\text { Inspiration Map - } \\
\text { exploration area }\end{array}$ & $\begin{array}{l}\text { Focusing on quantity, on average } 52 \text { elements of problem } \\
\text { understanding were generated. }\end{array}$ \\
\hline Categorizing the elements & $\begin{array}{l}\text { Understan } \\
\text { d }\end{array}$ & Be intuitive & $\begin{array}{l}\text { Inspiration Map - } \\
\text { exploration area }\end{array}$ & $\begin{array}{l}\text { The elements were allocated according to the items proposed by } \\
\text { the topics that compose the map. }\end{array}$ \\
\hline Translating the elements & $\begin{array}{l}\text { Understan } \\
\text { d }\end{array}$ & $\begin{array}{l}\text { Be intuitive } \\
\text { Inspire }\end{array}$ & $\begin{array}{l}\text { Inspiration Map -Insights } \\
\text { Definition / Persona }\end{array}$ & $\begin{array}{l}\text { Each group generated the personas that personified the problem } \\
\text { based on the elements identified. }\end{array}$ \\
\hline $\begin{array}{l}\text { Summarizing the information, } \\
\text { translating in a new challenge }\end{array}$ & $\begin{array}{l}\text { Understan } \\
\text { d }\end{array}$ & Inspire & $\begin{array}{l}\text { Inspiration Map - } \\
\text { Opportunity Definition }\end{array}$ & $\begin{array}{l}\text { The groups reduced the initial broad challenge to a relevant } \\
\text { opportunity for the user based on the elements identified and on } \\
\text { the persona. }\end{array}$ \\
\hline $\begin{array}{l}\text { Generating ideas for the solution } \\
\text { of the challenge }\end{array}$ & Create & $\begin{array}{l}\text { Be Generative } \\
\text { Be Creative Confident }\end{array}$ & Ideas Board & $\begin{array}{l}\text { The groups focused on generating a big quantity of ideas, } \\
\text { generating on average } 48 \text { ideas per group. }\end{array}$ \\
\hline Selecting ideas & Analyze & Be intuitive & $\begin{array}{l}\text { Ideas Board / Venn } \\
\text { Diagram }\end{array}$ & $\begin{array}{l}\text { After idea refinement, the groups selected an idea according to } \\
\text { design thinking criteria: desirability, practicability, and } \\
\text { feasibility. }\end{array}$ \\
\hline Planning ideas & Create & $\begin{array}{l}\text { Be creative confident } \\
\text { Be visual }\end{array}$ & $\begin{array}{l}\text { Ideas Board / Napkin } \\
\text { Pitch }\end{array}$ & $\begin{array}{l}\text { Based on the idea selected, the participants were supposed to fill } \\
\text { in a Napkin Pitch to develop the idea, by completing: the idea } \\
\text { description, the execution, user benefits and business benefits. }\end{array}$ \\
\hline Executing & Apply & $\begin{array}{l}\text { Be visual } \\
\text { Prototype }\end{array}$ & Ideas Board - Prototype & $\begin{array}{l}\text { The solution selected and developed should be prototyped by the } \\
\text { group, aiming to make the idea tangible and to enable initial } \\
\text { testing. The objective is the early identification of errors as a low- } \\
\text { cost improvement opportunity. }\end{array}$ \\
\hline Testing ideas & Analyze & $\begin{array}{l}\text { Iterate } \\
\text { Prototype }\end{array}$ & Elevator Pitch & $\begin{array}{l}\text { Brief presentation of the idea ( } 60 \text { seconds) to get the feedback } \\
\text { from the colleagues and the professor. }\end{array}$ \\
\hline
\end{tabular}

Source: Created by the authors 


\subsection{Structuring the experience}

Based on the stages and principles of design thinking (section 2) and difficulties in teaching design thinking (section 3), we began to structure the game. Previous experiences in design thinking teaching were used for its construction. As originally presented by Collins (1992), design science of education has to understand how different environments contribute to the learning process and how different designs contribute for better results.

The registered observations of these activities were relevant to improve and adjust the game, converging to its final version. Initially, the teaching process was focused on dynamics, aiming at generating a relevant and innovative solution at the end of the process. The logic of presenting a problem and building an innovative solution was kept, due to the importance of challenges and experimentation to enhance the learning process, as presented by Schon (1987), Barab et al. (2005) and Hwang et al. (2012). However, several adjustments were made to better differentiate insights and ideas and to avoid participants' rapid conversion to a solution without sufficiently exploring the problem. Furthermore, frequently the ideation process did not lead people to solutions that were creative enough. Thus, the game was adjusted to reinforce creative confidence and overcome the identified difficulties.

Besides, a minimum and a maximum time for the execution of the activity was identified, ranging between 2 hours and 30 minutes, as the minimum time to reach the results, and 4 hours, which is the maximum time a group can remain focused on the activity. These experiences were also very important to confront the desired results with the results actually achieved through the identification of participants' difficulties in the learning process.

The game is composed by two tables, one table focused on insight generation and the other focused on idea generation: (i) the inspiration map and (ii) the idea board. The inspiration map is composed of three main areas: (i) exploration map; (ii) insight definition; and (iii) problem definition.

In addition, some methods and techniques are used to support these stages, such as: Persona, Empathy Map, idea generation techniques, Venn Diagram, and Napkin Pitch. For each of these areas, a time interval is established to complete the area, according to the complexity of the step. The minimum time to complete the game is 2 hours and 30 minutes. The ideal time is 4 hours.

Figure 1 presents the relation between the principles, stages, and game. It is important to state that the principles are allocated at the moments where they are emphasized, but they are present to a greater or lesser intensity throughout all the stages of the game. 


\section{Figure 1}

The stages of design thinking integrated to principles and the game

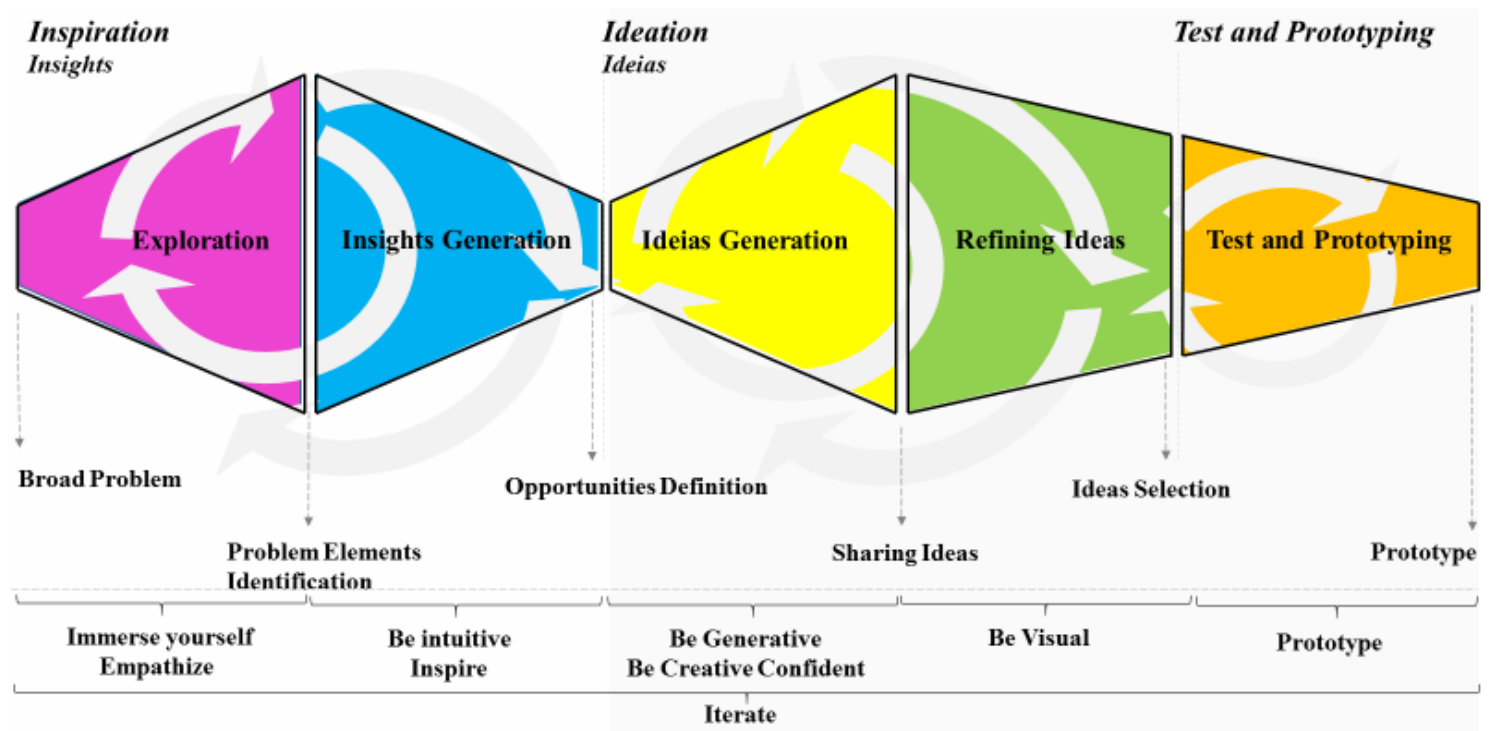

Inspiration Map

Ideas Board

Source: Created by the authors

Besides the learning objectives, there are two other factors that constitute the quality of a game: motivation and user experience. These two aspects are presented in Table 6 and Table 7, which portraits the factors, the categories that compose each one and the results observed and measured through the game application.

\section{Table 6}

Motivation objectives and specialist assessment

\begin{tabular}{l|l|l}
\hline \multicolumn{1}{c|}{ Objectives } & Categories & \multicolumn{1}{c}{ Experts evaluation } \\
\hline $\begin{array}{l}\text { Keeping participants focused on the } \\
\text { activity during the whole time of the game } \\
\text { execution }\end{array}$ & Attention & $\begin{array}{l}\text { Game structure kept participants focused on } \\
\text { the game. Game activities are well } \\
\text { positioned and are attractive to players. }\end{array}$ \\
\hline $\begin{array}{l}\text { Using the persona and the empathy map to } \\
\text { generate relevant results }\end{array}$ & Relevance & $\begin{array}{l}\text { Tools proposed enabled to identify relevant } \\
\text { opportunities. }\end{array}$ \\
\hline $\begin{array}{l}\text { Generating solutions during the game to } \\
\text { deliver value to the user }\end{array}$ & $\begin{array}{l}\text { Confidenc } \\
\text { e }\end{array}$ & $\begin{array}{l}\text { Based in the opportunities identified was } \\
\text { possible to generate solutions which deliver } \\
\text { value to the user. }\end{array}$ \\
\hline $\begin{array}{l}\text { Achieving a high degree of players' } \\
\text { satisfaction }\end{array}$ & $\begin{array}{l}\text { Satisfactio } \\
\mathrm{n}\end{array}$ & $\begin{array}{l}\text { Results achieved playing the game generated } \\
\text { a feeling of satisfaction. Game dynamic } \\
\text { made it pleasurable. }\end{array}$ \\
\hline
\end{tabular}

Source: Created by the authors 


\section{Table 7}

Motivation and user experience objectives and specialist assessment

\begin{tabular}{l|l|l}
\hline \multicolumn{1}{c|}{ Objectives } & Categories & \multicolumn{1}{c}{ Experts evaluation } \\
\hline $\begin{array}{l}\text { Forgetting what was happening in the } \\
\text { surroundings }\end{array}$ & Immersion & $\begin{array}{l}\text { Even in a four hours game, participants did } \\
\text { not see time passing }\end{array}$ \\
\hline Cooperatively interacting with teammates & $\begin{array}{l}\text { Social } \\
\text { interaction }\end{array}$ & $\begin{array}{l}\text { Game enables and stimulates team spirit } \\
\text { between participants, who focus on the } \\
\text { result and not on personal differences. }\end{array}$ \\
\hline Be challenging to the participants & Challenge & $\begin{array}{l}\text { Game structure challenges participants to } \\
\text { give their best to generate better solutions. }\end{array}$ \\
\hline Not being monotonous & Challenge & $\begin{array}{l}\text { The game structure, with boards, clear tasks } \\
\text { and limited time for activities motivates the } \\
\text { participants during the whole activity. }\end{array}$ \\
\hline $\begin{array}{l}\text { Learning in a fun way and be willing to } \\
\text { play again }\end{array}$ & Challenge & $\begin{array}{l}\text { Participants were satisfied with game } \\
\text { dynamics. Some specialists asked to play the } \\
\text { game in their reality. }\end{array}$ \\
\hline $\begin{array}{l}\text { Achieving results using previous } \\
\text { knowledge from the participants }\end{array}$ & $\begin{array}{l}\text { Competenc } \\
\text { e }\end{array}$ & $\begin{array}{l}\text { The game does not require previous } \\
\text { knowledge from the participants, since every } \\
\text { participant uses their own knowledge and } \\
\text { experiences to contribute to the team and } \\
\text { generate the best results. }\end{array}$ \\
\hline $\begin{array}{l}\text { Developing competences through the game } \\
\text { enpetenc }\end{array}$ & $\begin{array}{l}\text { The game helps in developing the } \\
\text { competences needed to innovate and solve } \\
\text { problems through the game. }\end{array}$ \\
\hline
\end{tabular}

Source: Created by the authors.

\subsection{Identifying resources and applying gamification elements}

The fourth stage, identifying resources, corresponds to the resources needed to gamify education. In this context, we developed two game boards and cards to support the idea generation for the idea board. These resources were selected based, mainly, on a design thinking principle, Be Visual, which seeks to make ideas visual through drawings. These drawings are placed on the board with post-it notes. Also, this creates an environment where everyone can access information at the same time in an interactive way.

The applying gamification elements stage is how the game will work. Characteristics of these elements applied to the game are presented in Table 8, detailing how each of them are applied to the Design Thinking Game.

For a better understanding of the game application Figure 2 presents a game application case with a group of university professors in southern Brazil. The application objective on this workshop, in particular, was the development of a product to contribute to the education of freshmen in the Architecture Course of the University. 


\section{Table 8}

Characteristics of the gamification elements applied to the game

\begin{tabular}{|c|c|c|}
\hline Elements & Concepts & Design Thinking Game application \\
\hline $\begin{array}{l}\text { Action } \\
\text { Language }\end{array}$ & $\begin{array}{l}\text { Refers to the method of } \\
\text { interaction. }\end{array}$ & $\begin{array}{l}\text { The game is played by groups, where each group must solve a } \\
\text { challenge in a collaborative and interactive way. }\end{array}$ \\
\hline $\begin{array}{l}\text { Assessment and } \\
\text { Progress }\end{array}$ & $\begin{array}{l}\text { Assessment: scoring } \\
\text { Progress: how players } \\
\text { advance toward the game } \\
\text { goals. }\end{array}$ & $\begin{array}{l}\text { Assessment: number of insights and number of ideas generated } \\
\text { scores are used to stimulate teams to be generative. } \\
\text { Progress: a time is set for each activity be performed. During this } \\
\text { time players should achieve the goals proposed. }\end{array}$ \\
\hline $\begin{array}{l}\text { Conflict / } \\
\text { Challenge }\end{array}$ & $\begin{array}{l}\text { Presentation of game } \\
\text { challenge; difficulty of the } \\
\text { game. }\end{array}$ & $\begin{array}{l}\text { The game is conducted based on a challenge that have a high } \\
\text { degree of abstraction, creating uncertainties to the possible } \\
\text { results. The results depend on each team's characteristic. }\end{array}$ \\
\hline $\begin{array}{l}\text { Control / } \\
\text { interaction }\end{array}$ & $\begin{array}{l}\text { Amount of active learner } \\
\text { control over content or } \\
\text { gameplay and the extent to } \\
\text { which the game changes in } \\
\text { response to player actions. }\end{array}$ & $\begin{array}{l}\text { The game relies on the interaction of player's ideas and vision to } \\
\text { build better solutions. }\end{array}$ \\
\hline Environment & $\begin{array}{l}\text { Where the player is and } \\
\text { how the player sees this } \\
\text { world. }\end{array}$ & $\begin{array}{l}\text { The game is based on real challenges, demanding that players use } \\
\text { and share their experiences and world perspectives with the team } \\
\text { to build solutions. }\end{array}$ \\
\hline Game fiction & $\begin{array}{l}\text { The nature of the game } \\
\text { world and story. }\end{array}$ & $\begin{array}{l}\text { The game world is based on real challenges, demanding that } \\
\text { players use their own experiences to reach objectives. }\end{array}$ \\
\hline $\begin{array}{l}\text { Human } \\
\text { interaction }\end{array}$ & $\begin{array}{l}\text { Deals with human-to- } \\
\text { human }\end{array}$ & $\begin{array}{l}\text { Human interaction happens all the time because all game } \\
\text { activities are collaborative and the game result is a product of this } \\
\text { interaction. }\end{array}$ \\
\hline Immersion & $\begin{array}{l}\text { The player's perceptual and } \\
\text { affective relationship with } \\
\text { the game fiction. }\end{array}$ & $\begin{array}{l}\text { Two points are to be highlighted in this element: the building of } \\
\text { the persona and the solution generated. } \\
\text { The persona comes to life by the team's participants, with name, } \\
\text { personality, face, and needs. The solution is the accomplishment } \\
\text { of a surprising result, since the participants could not even } \\
\text { imagine such result in such short time. }\end{array}$ \\
\hline Rules / Goals & $\begin{array}{l}\text { The degree to which the } \\
\text { game has clear rules and } \\
\text { goals. It determines the } \\
\text { method through which a } \\
\text { player can solve problems } \\
\text { in the game. }\end{array}$ & $\begin{array}{l}\text { The game has clear rules that seek to guide the actions of players } \\
\text { in order to accomplish the best team results: (i) all opinions are } \\
\text { welcome; (ii) do not judge or criticize; (iii) encourage others; (iv) } \\
\text { keep the focus on the problem; (v) hold one conversation at a } \\
\text { time; (vi) be visual - write down EVERYTHING!!!; (vii) focus } \\
\text { on quantity. }\end{array}$ \\
\hline
\end{tabular}

Source: Created by the authors 


\section{Figure 2}

Results of the game application

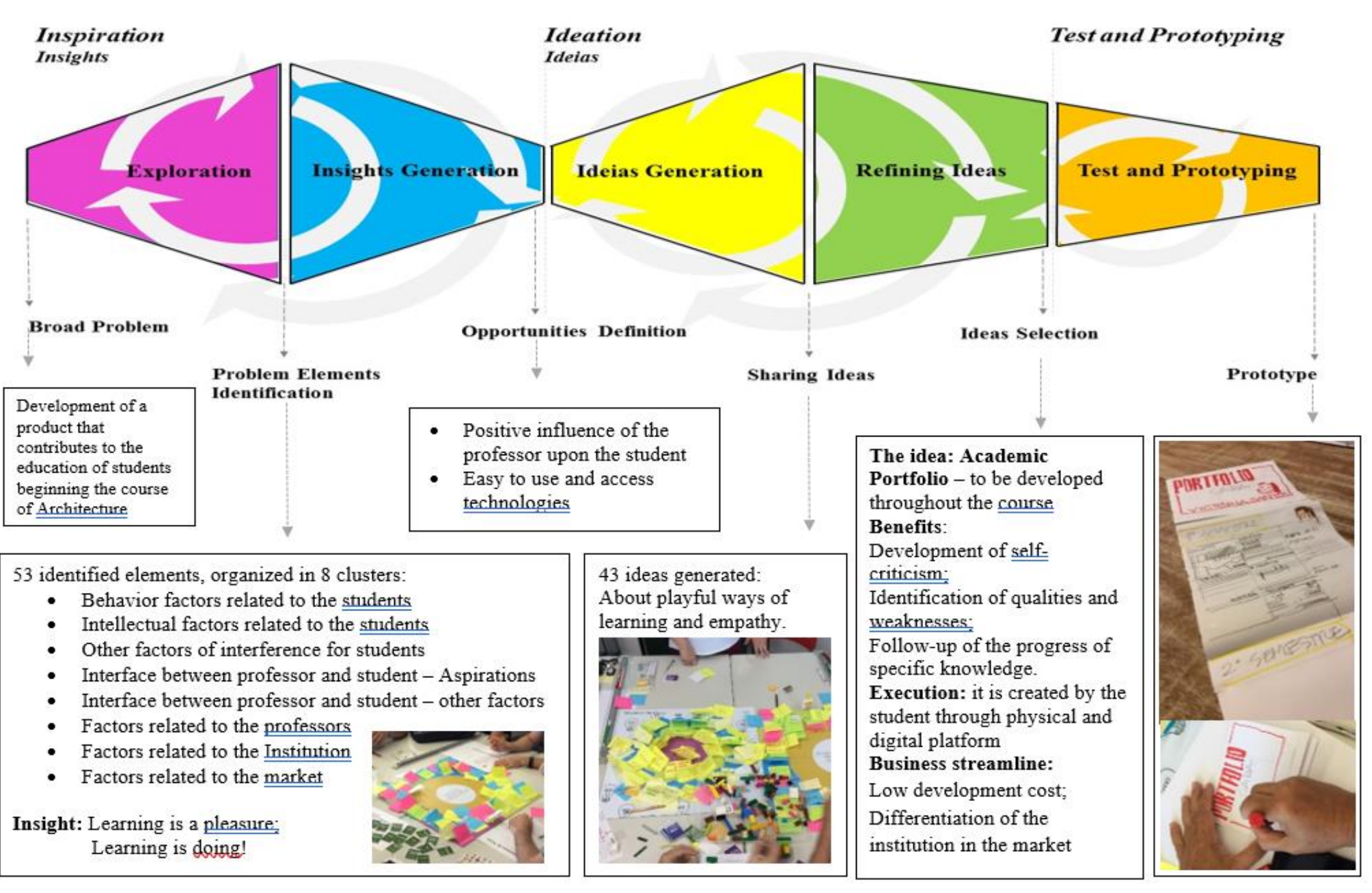

Source: Created by the authors. 


\subsection{Evaluation}

An evaluation was carried out with 67 people with three different profiles: (i) undergraduate students, (ii) professors and (iii) market professional. The groups observed in the game application had some elements examined through a survey based on the learning objectives of the Design Thinking Game.

There was no respondent identification to allow more independence in the answers. Most of the participants $(68,18 \%)$ had not had previous experiences with design thinking. Concerning their satisfaction towards the game, a seven-point scale was used ( 0 - totally unsatisfied; 1 - very unsatisfied; 2 - unsatisfied; 3 - neither satisfied nor unsatisfied; 4 satisfied; 5 - very satisfied; 6 - totally satisfied), in which $100 \%$ of the respondents claimed to be satisfied with the game (answers 4, 5 and 6), being $36.36 \%$ totally satisfied and $54.54 \%$ very satisfied. The results show that professors, students, and professionals enjoyed the game and found it useful as a learning instrument both to generate ideas and to find solutions for problems.

Based on this, it is possible to elicit that the game stimulates satisfaction, because, according to Kinzie and Joseph (2008), a game is immersive, voluntary, and enjoyable. Hwang et al. (2012) adds that, more than a pleasant experience, games engage students in the learning process and contribute to knowledge and skills development.

The participants also evaluated seven statements regarding the game's efficiency. This evaluation was done by using a five points scale (I totally disagree, I partially disagree, I neither agree nor disagree, I partially agree, I totally agree). Figure 3 presents the results. The vast majority of the respondents totally agree that the game contributes to: (i) better problem understanding, (ii) development of competences for design thinking (DT), (iii) understanding the difference between insights and ideas, (iv) better use of methods and techniques, (v) generation of a higher number of ideas, (vi) higher value delivery to users or clients and (vii) development of creative confidence. Still, regarding the problem understanding through design thinking, Hwang et al. (2012) argue that this is a critical skill for the problem-solving ability, including the problem-solving strategies - that are ideas generated through the game - and the process of choosing appropriate information and allocating proper resources -through the ideas selection with the Venn Diagram. 


\section{Figure 3}

Perception of 67 participants concerning the game's efficiency

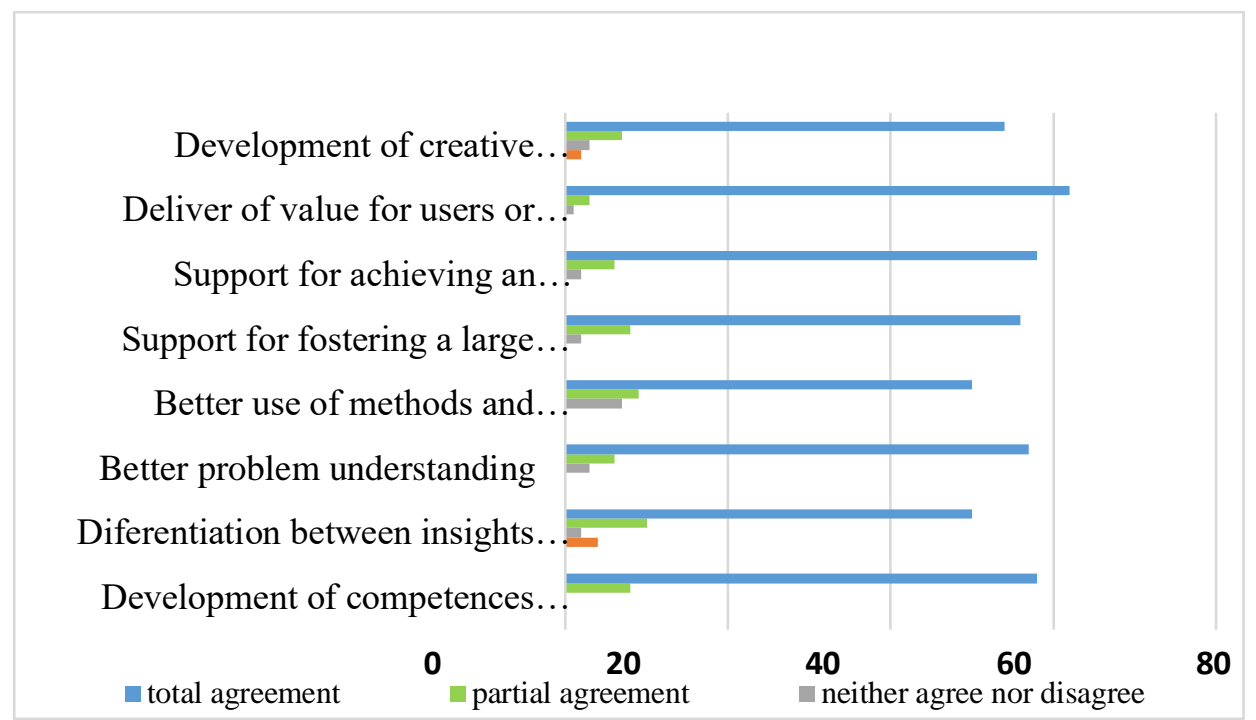

Source: Created by the authors

Hwang et al. (2012) point out students' difficulty to effectively and efficiently use collected information to solve problem. The game provides a holistic view of the proposed challenge to solve students' difficulty in use information. As Chen and Hwang (2014) point out, the game has a clear proposition focused on an effective learning strategy, based on tools and a theoretical background in a well-integrated way.

\section{Table 9}

Results of Fisher's least significant difference (LSD) procedure for comparing averages

\begin{tabular}{|c|c|c|c|}
\hline & Professors & Students & Professionals \\
\hline Satisfaction & 4,86 & 4,72 & 4,92 \\
\hline $\begin{array}{r}\text { Development of competences for design } \\
\text { thinking }\end{array}$ & 4,77 & 4,89 & 4,96 \\
\hline Differentiation between insights and ideas & 4,50 & 4,61 & 4,69 \\
\hline Better problem understanding & 4,77 & 4,78 & 4,88 \\
\hline Better use of methods and techniques & 4,50 & 4,50 & 4,88 \\
\hline Generation of a large amount of ideas & 4,64 & 4,94 & 4,88 \\
\hline $\begin{array}{r}\text { Support for fostering a large amount of } \\
\text { ideas }\end{array}$ & 4,82 & 4,89 & 4,96 \\
\hline $\begin{array}{r}\text { Support for achieving an appropriate } \\
\text { solution }\end{array}$ & 4,68 & 4,83 & 5,00 \\
\hline Deliver of value for users or clients & 4,86 & 5,00 & 4,92 \\
\hline Development of creative confidence & 4,64 & 4,56 & 4,88 \\
\hline
\end{tabular}

Source: Created by the authors based on research data. 
Using Fisher's least significant difference (LSD) procedure for comparing averages, the results show that professors, students, and professionals enjoy the game and find it useful both as a learning tool and also to generate ideas and find solutions to the problem under study. Considering the set of questions, on a scale from 1 to 5 , the general average resulted in 4.70 (for professors), 4.77 (for students) and 4.90 (for professionals). Although the evaluations of the three segments referring to the set of questions were notably positive (varying between 4.5 and 5.0) some differences between the segments were detected. In general, compared to professors and students, professionals assigned higher scores for the different aspects evaluated, with differences (small but statistically significant) in the aspects: better use of methods and techniques, support for achieving an appropriate solution, and development of creative confidence. It is possible that these results are due to the fact that, in the professional environment, because of the pressures of the daily routine, there is less time for using methods to reach optimal solutions. Thus, professionals were particularly satisfied with the characteristics of the game that support these aspects, assigning an average of 4.9 to better use of methods and techniques and development of creative confidence, and an average of 5.0 for the ability of the game to provide support for achieving an appropriate solution. Table 1 presents the results for all questions and segments. Interrupted bars assign statistical difference on a $90 \%$ confidence level.

\section{Discussion and final remarks}

This paper presented the design thinking principles and stages and a game to facilitate the learning process of design thinking. The principles identified and incorporated into the proposed game were: (i) iterate, (ii) immerse yourself, (iii) empathize, (iv) be intuitive; (v) be visual, (vi) inspire, (vii) be generative, (viii) prototype, and (ix) be creative confident. The identified stages, also incorporated into the game, were: (i) exploration; (ii) insights generation; (iii) ideas generation; (iv) ideas refinement; (v) testing and prototyping. To conduct these stages, methods and techniques were identified and incorporated.

Also, learning, motivation and user experience objectives were identified. The learning objectives tend towards two dimensions: (i) cognitive process dimension, and (ii) knowledge dimension. The objectives of the cognitive process dimension were: (i) identifying challenging elements, (ii) categorizing elements, (iii) translating the elements, (iv) summarizing the information, translating in a new challenge, (v) generating ideas for the solution of the challenge, (vi) selecting ideas, (vii) planning ideas, (viii) executing and (ix) testing ideas. 
Motivation objectives were: (i) keeping focused on the activity during the whole time of the game execution, (ii) using the persona and the empathy map to generate relevant results, (iii) generating solutions during the game to deliver value to the user, (iv) achieving a high degree of players' satisfaction. User experience achieved objectives were: (i) forgetting what was happening in the surroundings, (ii) cooperatively interacting with teammates, (iii) being challenging for the participants, (iv) not being monotonous, (v) learning in a fun way and be willing to play again, (vi) achieving results using previous knowledge from the participants and (vii) developing competences through the game.

The game was developed based on the identified gamification elements. Based on this, two boards were created (inspiration map and ideas board) to meet the proposed principles and stages of Design Thinking. The game provides an iterative passage through all stages of the design thinking, giving a holistic view of the process, starting with a deep understanding of the problem, and coming to a design solution. The results of the game application have shown its potential to: (i) ease teamwork, avoiding negative discussions and providing active participation from all students; (ii) lead to insight generation in a comprehensible way, making clear the difference between insights and ideas; (iii) simplify the use of inspiring methods and techniques (such as Persona, Empathy Map and Napkin Pitch); (iv) develop creative confidence; (v) provide a pleasant and motivating learning environment for collaborative multidisciplinary work. The experience of using the game revealed that: (i) the greater the number of thinking elements, the better the insights generated, (ii) the better the insights, the greater the number of ideas, and (iii) the greater the number of ideas, the better the result of the design solution generated. This conclusion was observed throughout many editions of courses taught, which shaped the final version of the game. Also, the game helped to solve difficulties regarding the understanding and implementation of design thinking.

The game requires the use of fewer methods and techniques than the complete set reported in the literature. However, since it conducts the student through all stages of design thinking, supported by a hands-on approach, the positive results of the learning process are evident. Concerning the learning process, we recommend using the game in the first contact with design thinking, due to the holistic view it offers through experimentation. Along with the game, a theoretical seminar may be presented to students, allowing a detailed discussion of principles, stages and techniques that may be employed in the design thinking approach.

The holistic and integrated view promoted by the game helps understanding and leading the innovative design solution. Considering the Design Thinking stages, there are two moments 
that should be emphasized. The initial moment, comprehending divergence and convergence, supported by the Inspiration Map, is associated to insight generation and involves understanding and exploring the problem. The second moment, also comprising divergence and convergence, supported by the Ideas Board, is related to the design solution. This approach is typical of the design thinking and avoids a precipitated convergence to a solution. The initial exploratory process, involving empathy and problem immersion, allows identifying and defining relevant issues related to people's real needs. The idea generation process allows exploring people's creative confidence, increasing the quality and comprehensiveness of the generated solution. The game structure leads to a better understanding concerning these topics.

This study has some limitations and results should be interpreted with caution. There're two aspects to be observed: sample (sample size, participants profile and the professor) and game's format. The results of this study are limited by the total sample size $(n=67)$, selected by convenience. The number of participants evaluated is relatively low compared with the number of people that used the game. Besides that, there's no control group learning without the support provided by the game, Such control group answering the same questions used to evaluate and compare the objectives assessed would strength conclusions. Another concern is the heterogeneous profile of the participants, which might have impacted perceptions and understanding about the game. An instrument for measuring students' competences for innovation could be used to provide a better characterization of the participants. This study is also limited by the geographical location, since all participants reside in Porto Alegre, a major city in southern Brazil. The last concern about the experiment is that the game sessions were always conducted by the same professor. This is positive concerning variability among sessions and groups' performance, but it doesn't ensures that the replication of the game by other professors would have the same results and impacts on its participants. Concerning the game's format, the present version uses a physical board. The evolution towards a digital panel could lead to new inferences and opportunities, enabling the enlargement of the game's scope and experiences.

Although the major part of the studies concerning games is based on computer games, the theoretical basis of the potential of transformation through this learning strategy is similar for digital or physical platforms. However, for future studies, the possibility of developing the proposed game for computers has been studied, as well as its applications. 


\section{References}

Akcaoglu, M. (2014). Learning problem-solving through making games at the game design and learning summer program. Educational Technology Research and Development, 62, 583-600. https://doi.org/10.1007/s11423-014-9347-4

Akili, W. (2015). Perspectives on Engineering Design Learning: Realities, Challenges, and Recommendations. IEEE. https://doi.org/10.1109/FIE.2015.7344190

Anderson, L.W., Krathwohl, D. R. (2001). A taxonomy for learning, teaching, and assessing: A revision of Bloom's taxonomy of educational objectives. New York:Longman http://eduq.info/xmlui/handle/11515/18345

Andreassen, T. W., Kristensson, P., Lervik-Olsen, L., Parasuraman, A., McColl-Kennedy, J. R., Edvardsson, B., Colurcio, M. (2016). Linking service design to value creation and service research. Journal of Service Management, 27, 21 - 29. https://doiorg.ez45.periodicos.capes.gov.br/10.1108/JOSM-04-2015-0123

Assaraf. O.B.Z. (2011). Learning from failure: a case study of where an extracurricular science program went wrong. Journal of Science Education and Technology, 20, 592607. https://doi.org/10.1007/s10956-011-9327-y

Barab, S., Thomas, M., Dodge, T., Carteaux, R., Tuzun, H. (2005). Makining Learning Fun: Quest Atalatis, A Game Without Guns. Educational Technology Research and Development, 53, 86-107. https://doi.org/10.1007/BF02504859

Barzilai S., Blau, I. (2014). Scaffolding game-based learning: Impact on learning achievements, perceived learning, and game experiences. Computers and Education, 70, 65-79. https://doi.org./10.1016/j.compedu.2013.08.003

Bedwell, W. L., Pavlas, D., Heyne, K., Lazzara, E. H., \& Salas, E. (2012). Toward a Taxonomy Linking Game Attributes to Learning An Empirical Study. Simulation \& Gaming, 43, 729-760. https://doiorg.ez45.periodicos.capes.gov.br/10.1177/1046878112439444

Bell R. L., Maeng J. L., Binns, I. C. (2013). Learning in context: technology integration in a teacher preparation program informed by situated learning theory. Journal of Research in Science Teaching, 50, 348-379. https://doiorg.ez45.periodicos.capes.gov.br/10.1002/tea.21075

Blumberg, B. F., Cooper, D. R., \& Schindler, P. S. (2014). Business research methods. McGraw-hill education.

Brown T, Katz B. (2009). Change by Design. New York: Harper Collings Publishers.

Brown, T. (2008). Design thinking. Harvard business review, 86.

Brown, T., Martin, R. (2015). Design for Action: How to use Design Thinking to make great things actually happen. Harvard Business Review, September Edition. 
Buchanan, R. (1992). Wicked Problems in Design Thinking. Design Issues, 8, 5-21. https://doi.org/10.2307/1511637

Burdick, A.; Willis, H. (2011) Digital Learning, digital scholarship and Design Thinking. Design Studies, 32, 546-556. https://doi.org/10.1016/j.destud.2011.07.005

Carlgren, L., Rauth, I., \& Elmquist, M. (2016). Framing Design Thinking: The Concept in Idea and Enactment. Creativity and Innovation Management, 25, 38-57. https://doiorg.ez45.periodicos.capes.gov.br/10.1111/caim.12153

Cervo, A., Brevian, P. (2002). Metodologia Científica. São Paulo: Prentice Hall. 5ed.

Chen, N.S., \& Hwang, G.J. (2014). Transforming the classrooms: innovative digital gamebased learning designs and applications. Educational Technology Research and Development, 62, 125-128. https://doi.org/10.1007/s11423-014-9332-y

Collins, A. (1992). Toward a Design Science of Education in Scanlon et al. (1992). New Directions in Educational Technology. Springer-Verlag Berlin Heidelberg.

Cowles, E., \& Nelson, E. (2015). An Introduction to Survey Research. Business Expert Press.

Cox III, E. P. (1980). The optimal number of response alternatives for a scale: A review. Journal of marketing research, 407-422. https://doi.org/10.1177/002224378001700401

Cross, N. (1982). Designerly ways of Knowing. Design Studies, 3, 221-227. https://www.jstor.org/stable/1511801

Davis, B. (2010). Creativity \& Innovation in Business 2010: Teaching the application of Design Thinking to Business. Procedia Social and Behavioral Sciences, 2, 6532 6538. https://doi.org/10.1016/j.sbspro.2010.04.062

Dichev C., Dicheva D. (2017). Gamifying education: what is known, what is believed and what remains uncertain: a critical review. International Journal of Educational Technology in Higher Education, 14, 1-36. https://doi.org/10.1186/s41239-017-0042-5

Dorst, K. (2011). The core of "Ddesign Thinking" and its application. Design Studies, 32, 521-532. https://doi.org/10.1016/j.destud.2011.07.006

Earle, A. G., \& Leyva-de la Hiz, D. I. (2020). The wicked problem of teaching about wicked problems: Design thinking and emerging technologies in sustainability education. Management Learning, https://doiorg.ez45.periodicos.capes.gov.br/10.1177/1350507620974857

Eppler, M.; Kernbach, S. (2016). Dynagramsn: Enhancing Design Thinking trough dynamic diagrams. Design Studies, 47, 91 - 117. https://doi.org/10.1016/j.destud.2016.09.001

Faiella F., Ricciardi M. (2015). Gamification and learning: a review of issues and research. Journal of e-learning and knowledge society, 11, 13-21. https://doi.org/10.20368/1971-8829/1072 
Ferreira, F.; Song, E.H.; Gomes, H.; Garcia, E.B.; Ferreira, L.M. (2015). New mindset in scientific method in the health field: Design Thinking. Clinics, 12.

Gleason, B., \& Cherrez, N. J. (2021). Design Thinking Approach to Global Collaboration and Empowered Learning: Virtual Exchange as Innovation in a Teacher Education Course. TechTrends, 65(3), 348-358. https://doi.org/10.1007/s11528-020-00573-6

Goodspeed, R.; Riseng, C.; Wehrly, K.; Yin, W.; Schoenfeldt, B. (2016). Applying Design Thinking methods to ecosystem management tools: Creating the Great Lakes Aquatic Habitat Explorer. Marine Policy, 6, 134-145. https://doi.org/10.1016/j.marpol.2016.04.017

Habraken, N.J.; Gross, M. (1988). Concept Design Games. Design Studies, 9, 150-158. https://doi.org/10.1016/0142-694X(88)90044-0

Hanus M.D., Fox J. (2015). Assessing the effects of gamification in the classroom: A longitudinal study on intrinsic motivation, social comparison, satisfaction, effort, and academic performance. Computers \& Education, 80, 152-161. https://doi.org/10.1016/j.compedu.2014.08.019

Hernández J.C., Palomo-Duarte M., Dodero J.M. (2017). Skill assessment in learning experiences based on serious games: A Systematic Mapping Study. Computers \& Education, 113, 42-60. https://doi.org/10.1016/j.compedu.2017.05.008

Ho, C-H. (2001). Some phenomena of problem decomposition strategy for Ddesign Thinking: differences between novices and experts. Design Studies, 22, 27-45. https://doi.org/10.1016/S0142-694X(99)00030-7

Holloway, M. (2009). How tangible is your strategy? How Design Yhinking can turn your strategy into reality. Journal of Business Strategy, 30, 50-56. https://doiorg.ez45.periodicos.capes.gov.br/10.1108/02756660910942463

Huang, W. H. (2011). Evaluating learners' motivational and cognitive processing in an online game-based learning environment. Computers in Human Behavior, 27, 694-704. https://doi.org/10.1016/j.chb.2010.07.021

Huang, W. H., Huang, W. Y., \& Tschopp, J. (2010). Sustaining iterative game playing processes in DGBL: The relationship between motivational processing and outcome processing. Computers \& Education, 55, 789-797. https://doi.org/10.1016/j.compedu.2010.03.011

Huang, W.H., Soman, D. (2013) A Practitioner's Guide to Gamification of Education. Research Reports Series, Behavioural Economics in Action. Rotman School of Management, University of Toronto.

Hussaini, S.; Vinnakota, T. (2015). Application of Systemic Design Thinking for Program Management. IEEE. https://doi.org/10.1109/TENCON.2015.7372931 
Hwang, G. J., Wu, P. H., \& Chen, C. C. (2012). An online game approach for improving students' learning performance in web-based problem-solving activities. Computers \& Education, 59, 1246-1256. https://doi.org/10.1016/j.compedu.2012.05.009

IDEO. (2015). The Field Guide to Human-Centered Design. Available at: http://www.designkit.org/resources/1. Access: January 82015.

Jiao J, Zhang R. (2015). Design thinking: a Fruitful Concept for Strategic Enterprise Management. International Conference on Education, Management and Computing Technology (ICEMCT), 1591-1594.

Jobst, B.; Köppen, E.; Lindberg, T.; Moritz, J.; Rhinow, H.; Meinel, C. (2012). The faithfactor in Design Thinking: Creative Confidence through education at Desgin Thinking School Potsdam and Stanford? In Plattner, H.; Meinel, C; Leifer, L. (2012) Design Thinking Research: measuring Performance in Context. Springer https://doi.org/10.1007/978-3-642-31991-4_3

Johansson, U.; Woodilla, J. (2009). Towards an Epistemological merger of Design Thinking, strategy and innovation. 8th European Acaddemy of Design Conference, Aberdeen, Scotland.

Jonassen D.H. (1994). Thinking technology: toward a constructivist design model. Educational Technology, 34, 34-37. https://www.learntechlib.org/p/171050/

Kelley, D., \& Kelley, T. (2013). Creative confidence: Unleashing the creative potential within us all. Crown Pub.

Kinzie, M. B., \& Joseph, D. R. (2008). Gender differences in game activity preferences of middle school children: implications for educational game design. Educational Technology Research and Development, 56, 643-663. https://doi.org/10.1007/s11423007-9076-Z

Koliji, H. (2016). Gazing Geometries: Modes of Design Thinking in Pre-Modern Central Asia and Persian Architecture. Nexus Network Journal, 18, 105-132. https://doi.org/10.1007/s00004-016-0288-6

Kordaki M., Gousiou A. (2017). Digital card games in education: A ten year systematic review. Computers \& Education 109, 122-161. https://doi.org/10.1016/j.compedu.2017.02.011

Krathwohl D.R. (2002). A Revision of Bloom's Taxonomy: An Overview. Theory Into Practice, 41, 212-218. https://doi.org/10.1207/s15430421tip4104_2

Leverenz CS. (2014). Design Thinking and the Wicked Problem of Teaching Writing. Computers and Composition, 33, 1-12. https://doi.org/10.1016/j.compcom.2014.07.001

Li M., Tsai C. (2013). Game-Based Learning in Science Education: A Review of Relevant Research. Journal of Science Education and Technology, 22, 877-898. https://doi.org/10.1007/s10956-013-9436-x 
Liedtka, J. (2014). Innovative ways companies are using Design Thinking. Strategy \& Leardership, 42, 40-45. https://doi.org/10.1108/SL-01-2014-0004

Liedtka, J. (2015). Perspective: Linking Design Thinking with Innovation Outcomes through Cognitive Bias Reduction. Journal of Product Innovation Management, 32, 925-938. https://doi.org/10.1111/jpim.12163

Liedtka, J., \& Ogilvie, T. (2011). Designing for growth. New York.

Liu, Y-T. (1996). Is designing one search or two? A model of Design Thinking involving symbolism and connectionism. Design Studies, 17, 435-449. https://doi.org/10.1016/S0142-694X(96)00018-X

Lloyd, P. (2017) From Design Methods to Future-Focused Thinking: 50 years of Design Research. Design Studies, 48, 1 - 8. https://doi.org/10.1016/j.destud.2016.12.004

Lockwood, T. (2009). Frameworks of Design Thinking. The Design Managemnt Institute. https://doi.org/10.1111/j.1942-5074.2009.00001.x

Luchs, M. in Luchs, M.; Swan, K. S.; Griffin, A. (2016). Design Thinking: New Product Development Essentials from the PDMA. John Wiley \& Sons, Inc.

Maydeu-Olivares, A., Kramp, U., García-Forero, C., Gallardo-Pujol, D., \& Coffman, D. (2009). The effect of varying the number of response alternatives in rating scales: Experimental evidence from intra-individual effects. Behavior research methods, 41, 295-308. https://doi.org/10.3758/BRM.41.2.295

McCain, R. A. (2014). Game theory: A nontechnical introduction to the analysis of strategy. World Scientific Publishing Co Inc.

Noweski, C.; Scheer, A.; Büttner, N.; Thiessen, J.; Endmann, J.; Mainel, C. (2012). Towards Paradigm Shift in Education Practice: Developing Twenty-First Century Skills with Design Thinking. In Plattner, H.; Meinel, C; Leifer, L. (2012). Design Thinking Research: measuring Performance in Context. Springer https://doi.org/10.1007/978-3642-31991-4_5

Olsen, N. V. 2015. Design Thinking and food innovation. Trends in Food Science \& Technology, 41, 182-187. https://doi.org/10.1016/j.tifs.2014.10.001

Oxman, R. (2004). Think-maps: teaching Design Thinking in design education. Design Studies, 25, 63-91. https://doi.org/10.1016/S0142-694X(03)00033-4

Palmer D. (2005). A motivational view of constructivist-informed teaching. International Journal of Science Education, 27, 1853-1881. https://doi.org/10.1080/09500690500339654

Patrício, R., Moreira, A. C., \& Zurlo, F. (2020). Enhancing design thinking approaches to innovation through gamification. European Journal of Innovation Management. https://doi.org/10.1108/EJIM-06-2020-0239 
Petri G., Wangenheim C.G. (2017). How games for computing education are evaluated? A systematic literature review. Computers \& Education, 107, 68-90. https://doi.org/10.1016/j.compedu.2017.01.004

Preston, C. C., \& Colman, A. M. (2000). Optimal number of response categories in rating scales: reliability, validity, discriminating power, and respondent preferences. Acta psychologica, 104, 1-15. https://doi.org/10.1016/S0001-6918(99)00050-5

Qian, M., Clark K.R. (2016) Game-based Learning and 21st century skills: A review of recent research. Computers in Human Behavior, 63, 50-58.

https://doi.org/10.1016/j.chb.2016.05.023Get rights and content

Rao, H., Puranam, P., \& Singh, J. (2021). Does design thinking training increase creativity? Results from a field experiment with middle-school students. Innovation, 1-18. https://doi.org/10.1080/14479338.2021.1897468

Rylander, A. (2009). Design Thinking as Knowledge work: Epistemological Foundations and Practical implications. Journal of Design Management.

Sato, C. (2009). Effective Management of Core Competency for Creating Product Innovation. IEEE. https://doi.org/10.1109/ICIEEM.2009.5344286

Sato, S.; Lucente, S.; Meyer, D.; Mrazek, D. (2010). Design Thinking to make organization change and development more responsive. The Design Management Institute. https://doi.org/10.1111/j.1948-7169.2010.00064.x

Schön, D. A. (1987). Educating the reflective practitioner: Toward a new design for teaching and learning in the professions. Jossey-Bass.

Seidel V, Fixson S. (2013) Adopting Design Thinking in novice multidisciplinary teams: The application and limits of design methods and reflexive practices. The Journal of Product Innovation Management, 30, 19-33. https://doi.org/10.1111/jpim.12061

Shih, S-G.; Hu, T-P.; Chen, C-N. (2006) A game theory-based approach to the analysis of cooperative learning in design studios. Design Studies, 27, 711-722. https://doi.org/10.1016/j.destud.2006.05.001

Sköldberg, U.; Woodilla, J.; Çetinkaya, M. (2013) Design Thinking: past, present and possible futures. Creativity and innovation management, 22. https://doi.org/10.1111/caim.12023

Stickdorn M, Schneider J. (2012) This is service Design Thinking. New Jersey: Wiley \& Sons.

Talbot, R. J. (1973). Games for design education. Programmed Learning and Educational Technology, 10, 259-266. https://doi.org/10.1080/1355800730100406

To, S. M., \& Liu, X. (2021). Outcomes of Community-Based Youth Empowerment Programs Adopting Design Thinking: A Quasi-Experimental Study. Research on Social Work Practice. https://doi.org/10.1177/10497315211001442 
Uehira, T.; Kay, C. (2009) Using Design Thinking to improve patient experiences in Japanese hospitals: a case study. Journal of Business Strategy 30, 6 - 12. https://doi.org/10.1108/02756660910942418

Vianna, M.; Vianna, Y.; Adler, I.; Lucena, B.; Russo, B. (2012). Design Thinking: Inovação em Negócios. Rio de Janeiro: MJV Press, 162p.

Ward, A.; Runcie, E.; Morris, L. (2009). Embedding innovation: Design Thinking for small enterprises. Journal of Business Strategy, 30, 78-84.

https://doi.org/10.1108/02756660910942490

Zikmund, W., Babin, B., Carr, J., \& Griffin, M. (2012). Business research methods: Cengage Learning. H4 B. Journal of Small Business Management, 44, 268-284. 